tronised; but the additions of the editor are letter, it would be more advisable to wait a extremely scanty, and the critical enquiry liitle, until the Government shall ordain the into the practice of surgery, announced in decimal proportions of weights and measures the title page, appears to have been entirely to be generally used, which we anticipate omitted; at least, we do not find it in the so seo done in a few years. copy before us.

\section{PROPOSAL To PUBLISH AN ANNUAL PHARMACOPCEIA BRITANNICA.}

$W_{\mathrm{E}}$ have just received the following letter, which we are requested to insert; our doing so, however, is not to be construed into an approval of its contents. If pharmacopœias be of any use, a national pharmacopoia must be better than three; but the plan of bringing out a new one annually is more than the progress of pharmacology requires, and would impose a heavy annual tax upon the general practitioner.

A supplement might be annually printed, containing all the improvements made in the year, which might be sold at a low price, and every ten years the additional matter might be embodied in a new edition. In this way the National Pharmacopeia would keep pace with the knowledge of the times, and be productive of some good, by preventing the numerous mistakes which now happen in consequence of certain medicines being compounded after different formulæ. But the fact is, that very little attention is at present paid to pharmacopoias, on account of the slovenly and unscientific manner in which they have been got up, and of the long interval allowed to elapse between their appearance; for, as Dr. DuscAN has acknowledged, "several important medicines have not had a place in the pharmacopocia of any of the three colleges for many years after they have been in common use with almost every intelligent practitioner."

Instead of adopting an alteration of weights for pharmacy, as proposed in this
This is our opinion respecting the phar macopœia and the weights, which appear to us the only feasible, or indeed rational parts of the letter.

$A$ Letter to the Royal Colleges of Physicians of London, of Dublin, and of Edinburgh, from Andrew Duncan, Sen. M. D. and Prof., first Physician to the King for Seotland, Father of the Royal College of Physicians of Edinburgh, \&c., respecting a proposal for the improverrent of medicine, by publishing annually, under the authority of these three Royal Colleges, a Pharmacopeia Britanuica.

Non fasces non purpuram, non exstructas in altum divitras, non ingenium artibus atque scientiis ut cunque ornatum et imbutum, sed animum commu ni utilitate inservientem dignitas sequitur.

Nichols, Oratio Harveiana.

Gentemen,-I need not tell you, that the Colleges of Physicians of London, of Dublin, and of Edinburgh, established at an early period by Royal Charters, have always been considered as the councils of health for the respective kingdoms to which they belong. In this capacity, they hare published, in an improved form, when they thought it necessary, pharmacopoias regulating the composition of medicines, each for the kinglom over which their jurisdiction extended. But England, Ireland and Scotland are now so intimately connected, that no one can possibly be ignorant of the many inconveniences which must arise from three different pharmacopœias for regulating the practice of apothecaries in the composition of medicines in different parts of the Bricish empire. The benefits that would retult from one Pharmacopoia Britannica, regulating the practice of apothecaries over the whole, are too obvious to require being mentioned. On that subject, it is, I think, impossible there can be two opinions.

A Pharmacopoia Britannica could only indeed be obtained by a solemn act of the Legislature. But if the three Royal Colleges were to unite in applying for such an act, there can be little doubt that it would be obtained. That act might be so framed, as to be productive of many other advantages to the rational and intelligent physician, in employing his endeavours in the cure of diseases. Among other particulars, it might be so framed as to produce a complete and entire separation between the 
honest and intelligent apothecary and the common use with almost every intelligent daring and impudent empiric. The sale of practitioner.

pharmacopoia medicines might be entirely confined and secured to the former; while the latter might still be allowed freely to employ all his art in extending the sale of his infallible nostrums at any other shop he may incline, excepting the shops of those regularly licensed by Government to sell pharmacopcia medicines. From this separation by legal authority, there cannot be a doubt that much real benefit would be obtained.

But, besides this, such an Act of Parliament might introduce into the shop of the regularly licensed apothecary, many important improvements. Among others, it might lead to an useful reformation in weights used in the shops of apothecaries, and to a more speedy introduction into these shops of every article which may be hereafter discovered to be really useful in the cure of disease.

The weights hitherto employed, grains, scruples, drachms. ounces, and pounds, are attended with many inconreniences. On this subject, without adopting the new French weights, I would yet imitate them, by adopting decimals. I would continue the present grain as the basis ; and I would adopt as multiples of it decigrains, centigrains, and millegrains. Of these millegrains, ten should form the libe*. The libe, again, might be increased in a decimated progression, as well as the grain, its multiple being a decilibe, a centilibe, and a millelibe. From this standard for weight, it cannot, I think, be doubted, that many important advantages would arise, both to the physician and to the apothecary.

Another obvious benefit that might be obtained by an fict of Parliament, is an annual improvement of the Pharmacopœia Britannica, corrected according to the progressive discoveries made in the practice of medicine. It has hitherto been the uniform practice of all the tbree Royal Colleges, to improve their Pharmacopoias, not gradatim, but per saltum, as it may be termed. They hare published new editions only at the end of ten, twelve, or sometimes even more than twenty years. By this means, the alterations have necessarily heen very considerable, and have often led to an almost total change of language, both in prescription and in the shops of the apothecaries. Several important medicines have not had a place in the Pharmacopocia of any of the three Colleges for many years after they have been in

* A term derived from the Latin word librt, though much hearier than the present pound of apothecaries' weight.

These great inconveniences might be ef. fectually avoided by an annual standard Pharmacopœia, with an imprimatur from all the three Royal Colleges, being printel every year at the expense of Government. This new impression, conjoined with a licence to keep an apothecary's shop, might be distributed by the Stamp-office; each individual who shall receive a licence for the year, paying at the rate of two guineas annually, for a stamped licence and a copy of the Pharmacopocia. From the sum thins collected by the Distributor of Stamps, an adequate allowance might be made to an intelligent physician, appointed by Govem. ment, to prepare the annual Pharmacopoid. From the money thus collected, the full ex. pence of printing and distributing this annual Pharmacopoeia might be defrayed, and even some addition made to the general re. venue, as well as from the licences for the sale of tea, wine, or other articles.

Of such an act of the legislature, it mar naturally be concluded, that very different opinions will be formed; and I am fully sensible that it is liable to many objections. But the evils that might be apprebended from it are, in my opinion, of very little weight when put in the scale against the numerous advantages which would result from it. And to submit it more fully to the serious consideration of the three Colleges I here subjoin what I think might be the heads of a Bill which might be proposed hy the three Royal Colleges of Physicians fo: the sanction of the British Parliament. If conduct in suggesting such a Bill will, 1 doubt not, be blamed by many. But I can at least answer for my intentions. Thep are honest, rational, and even merit approbation. And, I am persuaded, I need not request that each of you will bestow upon them a serious consideration.

I have the honour to be,

Your most obedient serrant,

Andrew Dincan, sen. at. 8

Edinburgh, Oct. 1, 1826."

Proposed Heads of a Bill for romlating th Practice of Pharmacy in the Brition Empire

\section{Be it enacted,}

That, in place of three Pharmacoptins which are at present published by authoris of the Royal Colleges of Physicians of Los: don, of Dublin, and of Tdinburgh, for reguld th ing the practice of Pharmacy in Fnglan, Ireland, and Scotland, there shall be but on? Pharmacopocia, under the title of $\mathrm{T}_{\mathrm{HF}} \mathrm{P}_{\mathrm{H}} \mathrm{A}$. madopcera Britannica, for regulating te 
practice of Pharmacy over the whole of the British Empire.

That of this Pharmacopeia Britannica, a corrected and improved edition shall be published on or before the 1st of January every year, to be the standard for every apothecary during the course of that year.

That this corrected edition shall be prepared by a Physician appointed by the King, under the title of Royal Pharmacopolist.

That, prior to its publication, it shall receive an imprimatur from the Presidents of the Royal Colleges of Physicians of London, of Dublin, and of Edinburgh.

That no shops shall be permitted to sell Pharmacopæia medicines, excepting those which are kept by apothecaries who have obtained a licence from Government for that special purpose.

That no apothecary licensed by Government to vend Pharmacopoia medicines, shall keep in his shop, or sell any other articles whatever but those which are introduced into the Pharmacopœia Britannica.

That the grain weight at present in use in the shops of apothecaries, shall still continue to be the basis of the weights used by apothecaries in the composition and sale of medicines; but that in place of the other denominations which are at present in use, the larger weights shall be increased in decimal progression, under the denominations of decigrains, centigrains, and millegrains ; of libes, decilibes, centilibes, and millelibes; every superior denomination consisting of ten of the inferior.

That, both in the composition and sale of medicines, weight only shall be employed, and that recourse shall never be had to measure in the shops of the apothecaries."

It is very evident, from a slight glance at this document, that Dr. Avdrew Duxcas, senior, is not acquainted with the present condition of the profession in this country; he has fallen into exror in common with many of his countrymen, in supposing that there still exists such a tribe of beings as were formerly denominated apothecaries; he talks of "hunest and intelligent apothecaries," kut the race in England is extinct. As to his " Royal Pharmacopolist," and his "two guinea stamped licence," he ought to know that no benefit can accrue to any science from its being put under the protection of the Stamp Office. "The Father of the Royal College of Plysicians of Edinburgh," has yet to learn the principal of medical legislation, and unless he separates

No. 166. the Pharmacopceia Britannica from the absurd proposals with which he has coupled it, he will find that his whole scheme will be rendered abortive.

WE feel it but justice to explain so much of an article which appeared in the 156th Number of The Laxcet, as relates to the conduct of the late Censors of the College of Physicians, as Trustees ex officiis of the Hunterian Museun, which, prima facie, and in the absence of the "terms and conditions," alluded to in our last, appeared to furnish matter for indignant comment, inasmuch as the exclusion of the Licentiates of the College of Physicians from the Mruseum of Hunter, seemed to emanate from them. But in this we were mistaken; and we take this opportunity of setting ourselves right with the Censors and the public, more especially as the Editors of the Medico-chirurgical and Yellow Journals, affecting private information, and God knows what besides, have copied our errors, and railed at the Trustees in good set terms of fustian and bombast, withont, in truth, knowing aught of the matter. In our own vindication we have only to observe, that the obnoxious regulation was put forward, ostensibly, as the act of the Trustees-as their resolution, and not as it should have been, as a mere enforcement of a primordinate law which they had no power to abrogate of alter. So much for ourselves. As to Dr. Macleod, he talks of the " afficious interference of the censors," as if it were "offi. cious," to interfere, to do what Parlia. ment designed them, and what they had sworn by the Evangelists to perform!

It is more handsome, according to Dr. Macleod to wink at failings, than to blaze them abroad; better to bask in the sunshine of hole and corner favour, than to drudge in the laboratory of truth; more honest to publish "faix" and "successful cases," than to put men to "demoniacal torture," by expose 
ing their failures and want of dexterity,-and honores of the northern fair one, could hare argues greater "taste and judgment," to inflicted the deadly wound on her repun neglect the most important and sacred duties, tation :-

than scrupulously to perform them. "I never was any where," says the man in the play, "but all manner of folks loved me most dearly;" and the bospital gentry have shown such extraordinary affection for poor Dr. Macleod, that we will be sworn he has exhibited all the agreeable, tractable, and trust-worthy qualities, which gained so much favour for his prototype. Indeed, he bids fair to make more friends than the obsequious and obliging Johnson, who has "sentiments of respect and esteem," or some such a compliment, for every one that falls in his way. In his last $\mathrm{N}^{\top}$ umber, this worthy talks of the " march of intellect," and of the " disgraced title of Licentiate," which he, nevertheless, reckons the first of his "blushing konours," and so places it on the cover of his Review!

"We have reason to believe," he says, " that tle Board of Curators of the Flunterian Miseum mean to pay no attention to the liberal recommendation of the Trustees, not to permit the visitations of Jirglish Licentiates, or Scottish graduates, without a permit from the London Colleges ;" but as. we also have reason to believe, and have shown, that snch " liberal recommendation" was never made, and that neither the Board of Curators, nor the Trustees, have power to alter the laws which parliament gave them, there is an end of the matter. Drs. Johnson and Macleod have suffered much mortification, God knows, for adopting the error which we unfortunately promulgated; and the latter has received a severe lashing from "A friend of the late Censors," in our last LANCET, so that it were unnecessary to add more to their ignominy, or their pain.

We set down the following to the phases of the moon, not supposing that any one in his senses, who has received the summi benefit.

"It is very evident," says the sage, " that medical men in England, who have sons bringing up with a view of practising as physicians, will, very geverally, push them through that channel which leads to a Fellowship of the London College. If they do not, they will be guilty of a crime much worse than thut af infanticide!"

This is pretty well for a man who has ground, and gracluated beyond the Tweed; But he has something better. If men cannot get an Oxford or a Cambridge diploma, he says, let them get " a good surgical education, in order that they may earn their bread respectably and independently as surgeons; but let them beware of the disgraced title of Licentiate !" Who would hare dreamed that a Scotch diploma and the license of the College, are incompatible with respectability and independence; or that Dr. James Johnson, the holder of both, would be the first to make the discovery! We must allow him to know something of the matter, as far as it relates to himself; but we protest that it argues very bad taste to blazon it forth to the pullic. A man can only be disgraced by his own acts, and $\mathrm{D}$. James Johnson best knows how far he is culpable, but must not be allowed to apply his sweeping epithets to the great and respectable body of the fraternity to whicl he happens, so much against his will, to belong.

Sir Asteey Coopen, at the particular request of the KING, has lately visited the Durs of York, and on the first occasion his Mrajesty was pleased to meet the $\mathrm{H}_{0}$. nourable Baronet at the Royal Duke's resio dence; the interview lasted a considerable time. The Dune of Yorh's discase is genle. ral anasarca, a form of dropsy the most difficult to remove. Sxr Astuey prescribed n combination of squill root and lue pill, whicl we understand has been taken with some 
IN our last Number we inserted the ac- to ground the comments which we intend counts of the London Ophthat.Mic InterMary, as published in the Annual Reports, up to March 1808, and we shall now place before our readers the various items of expenditure duxing two other years, viz. 1823 and 1824:-

1823.

By Butcher, Baker, and Coal Merchant ............. 18214

By Brewer, Chandler, and Cheesemonger $\ldots \ldots \ldots \ldots \ldots \ldots$. By Iivdicines, Drugs, and Leeches ...............

By Surgical Instruments and Optical Glasses........... Bedding and Furniture........ By Carpenter, Mason, Plumber, Glazier, and Smith ........

By part of last Anniversary Ex-

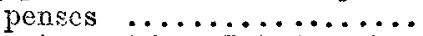

By Advertising, Printing, Stationary, Stamps, and Postage

By Insurance agrainst Fire and Gas Lights .............

By Disbursements in Housekeeping ................

By Wages and Gratuities ....

By Collector for Commission, and Extra Service.........

1894.

133

$\begin{array}{lll}9 & 15 & 8\end{array}$

$\begin{array}{lll}83 & 8 & 8\end{array}$

660

9118

2260

$\begin{array}{lll}56 & 12 & 9\end{array}$

$217 \quad 13 \quad 2$

$34 \quad 7 \quad 6$

861149

-

To Butcher, Baker, and Coal Merchant ............ 144 14

To Brewer, Chandlex, and Cheesemonger ...............

To Medicines and Mrugs......

To Surgical Instrúments and Optical Glasses .............

To Carpenter, Mason, Plumber, and Glazier ...........

To Advertising, Printing, Stationary, and stamps ........

To Insurance against Fire ....

To Paxes and New River Water

To past Aniviversary Expenses, $1823 \ldots \ldots \ldots \ldots \ldots \ldots$

To House-keeping Disbursements................

To Collector for Commission and Extra Serrice...$\ldots \ldots \ldots$

These statements, taken promiscuously from the various annul "Reports" now lying before us, are sufficient data whereon to offer respecting the financial and pufing departments of this pretended Charity. In February 1810, the Institution was deprived of the services of Mr. SAUNDERs, its projector, that Gentleman having departed this life on the 9tin of the above month; he was succeeded by Mr. Travers. Up to this period, only two pupils had been permitted to witness the practice of the Infirmary; and although Mr. Savidens had boasted for some years previous to his death of having operated in a peculiar manner on very young infants who had congenital cataract, yet, up to the time of his decease, he had not communicated the particulars of his method of operating to the medical profes. sion of his comntry; but more of this anon. Shortly after the election of Mrr. Travers, a second surgeon was appointed in the person of Mr. LAw RENeE, and in 1814 ! studentswere armitted to witness the practice of the Infirmary at the following charges-five guineas, three months' attendance; eight guineas, six months; and ten guineas, twelve months. About five years since, the BUSINEs of this Institution xas removed from Charter House Square to Moorfields, where a building was erected, known by the name of the London Ophthalmic Infirmary, at a cost of nearly ten thousand pourds, which, we fear, was rather unwitingly subscribed by a too creduious public.

It is, we conceive, unnecessary to enter at greater length into the minute history of this Institution; we shall now, therefore, direct our attention to certain transactions connected with its gorernment, which, when explained, cannot fail to convey to the minds of the Governors, a perfect knowledge of the deceptions which have been practised, and of the true objects of certain busy percons who have, unfortunately for the Establishment and the pubic, taken a too active part in its government. Let us, therefure, begin with the beginnirig, and proceed to inquire how far the state- 
ments contained in the projector's prospectus have been verified; how far the eulogiums so unsparingly bestowed upon $\mathrm{Mr}$. SAUNDERs in the annual reports were merited by that individual, and whether the anticipations of the benevolent Governors, who subscribed towards the establishment of this Infirmary, have been fully or even in part realized. An attentive perusal of the prospectus at once conreys the idea, that one of its chief objects was to institute a scroor for the study of Ophthalmic Surgery. The following paragraph surely warrants this conclusion.

"The structure of the eye and the ear is so delicate and complex, and their irritability under injury so extreme, that they cannot easily be treated but by those who make them the objects of peculiar study and attention. The acknowledged dificulty in the treatment of the diseases to which they are liable, has induced a few to separate themselves from the practice of professional duties, and to devote themselves to the exercise of this branch alone; a fact which sufficiently establishes the expediency of making them the objects of a specific institution."

Thus the governors were evidently betrayed into a belief, that it was the intention of the projector to establish a school for the investigation and study of those diseases which are peculiar to the eye and the ear; but was it the intention that it should become an arena accessible to the public for those purposes? Of motives it is at all times difficult to speak with any degree of certainty; of actions, however tortuous their course, we can comment without fear of misrepresentation; here we have data which we can clearly observe, and the movements of individuals are as manifest to others as to ourselves. It is the same with respect to the tendency of actions; but in the attempt to investigate, to analyse motives, our labours often become bewildered in the intricacies of hypocrisy and intrigue. In the present case, our exertions are of a lighter kind, because the projector and his supporters have furnished us with such materials, that there can be no diff. culty in producing the instruments of their damnation from their own hands. The Londem Ophthalmic Infirmary waS NOT IXILN. DED For a SCIEXTIFIC SURG1CAL SCHOOL, its doors having been closed against those wlio were desirous to become pupils there until the fourteenth of June, one thousand eight hundred and fourteen; and from its esta. blishment in March, 1805, until February, 1810, at which period the projector died, there was practised within its walls an operation which it was pretended was one of a peculiar character, and, as such, sedulously kept from the knowledge of the surgical pro. fession. It is true, that during this time, two parsons, Sir William Adams, and Mr. Stevenson, the private friends of Mr. Saun. ders, were permitted, as a matter of mighity favour, to become acquainted with the legerdemain tricks of the secret operator; and these constituted the entire number of scholars during a period not only of five, but of NINE YEARs, as the doors of the Institu. tion were not thrown open for the admission of pupils, (and then at a charge of five or ten guineas each,) until the year one thou. sand eight hundred and fourteen, being nine years after it was founded; yet in the annual reports, penned, we are informed, by Dr. FARRE, it appears that the surgeon was thanked by the Governors for com. pletely humbugging them; that he was hell up to the public as a "benefactor to the human race," and " one of the brightesi ornaments of the medical profession:" in. deed, so extraordinary were his merits, that Messrs. Farre, Battley, and Co., expended upwards of sixty pounds in advertising them, of which we may say, that a piece of moue gross or palpable quackery was neret practised in this quacking metropolis. It is with regret, deep regret, that we wite one syllable which can reflect discredit on thecharactex of the dead, but we holl our duty to the living to be paramount to every other consideration; for should such 
nefarious practices be tolerated, which have / our own, as we should be sorry to lessen been sanctioned by the conductors of this institution, the medical profession would soon sink into irretrievable disrepute, and the names of surgeons and physicians would form as many blots on the pages of its history.

The abettors of the quackery which obtained at this Infirmary, are, in every respect, as culpable as was the quack himself; he was upheld by them, supported by them, and even now they are exercising the full measure of their nefarious traffic. The tale which we now unfold, will, we hope, convince the Governors that they have been most shamefully deluded; that their ulms have been most infamously bestowed, and their benevolent intentions for the greater part, entirely frustrated. Let them inquire of Dr. FARRE, and his colleague the Druggist, why pupils were not admitted into the Infirmary until nine years after its establishment. 1)r. FarRE, the coadjutor and biographer of Mr. Satrders, speaks of that gentleman in the most glowing terms of eulogy; and in reply to some individuals who had spoken rather reprehensively of the "Hole and Corner" manner in which the surgical business of the Infirmary had been conducted, the Doctor thus valliantly writes: "Finally, if his enemies would search into his very bosom, his private correspondence is now open to their examination." Now it happens that we possess a portion of Mr. Saunders's private correspondence, and as it furnishes indisputable testimony of the real motives of the writer for concealing his operation from the profession, we will, as the Doctor seems to be so ignornt on this point, enlighten his understanding, and gratify him with a sight of it ; indeed, it is so argumentative, so conclusive, and gives such a peculiar impress to the memory of Mr. Sluxders, to the scientific and liberal characters of his colleagues in humbug, puffing and secrecy, that we will here insert it, without adding another word of the effect which it ought to produce on the mind of the professional reader :-

MY Detr $\operatorname{Srr}$,

London, 2d Jan. 1809.

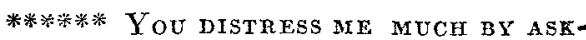
ING FOR MY MODE OF OPERATING ON CHILDREN BORN BLIND WITH CATARACT, and $I$ hope, when $I$ decline it, you will consider me as acting contrary to my natural temper and disposition. You must be acquainted with my situation here, with two opponents engrossing the public attention. From the free communication between medical men, if I had made many acquainted with it, mY OPPONESTS WOULD HAYI KNOWN IT BEFORE Now, AND BEEN ACTING UPON $\mathrm{IT}$, sfoghat $I$ should have lost the credit which if have now gained over them, by doing what they decline; only two people, of whom Mr. $\mathrm{O}$. is one, are acquainted with my notions, and these are most intimate friends, who have been in the closest contact with me, and from whom 1 conceal nothing. Mr. Cooper, WHO HAS REPEATEDLY ASKED ME, DOES NOT KNow IT. After this I trust you will excuse me, for I should give just cause of offence to him and many other friends who have asked me in vain, but have been satisfied with my reasons, considering the predicament in which I gtand." * *

$$
\begin{aligned}
& \text { Yours, faithfully, } \\
& \text { J.SAlnders. }
\end{aligned}
$$

We shall return to this subject again and again,

\section{ON THE ART OF BAKING BREAD,}

The popular turn of late years given to the study of chemistry has led to many valuable discoveries in the arts, and has mainly contributed to support that pre-eminence which the manufacturers of this country hold over those of all others. Much has been done by the chemists of Paris, and by the Polytechnic School of Yienna, to excite a general taste among the people of these countries for this interesting and useful science; but thus far the population of this kingdom has outstripped tiat of any other portion of the giobe in a practical acquaintance with this branch of physics. It is impossible to select any class of society to 